\title{
Atatürk üniversitesi Tıp Fakültesi çalışanlarında kilo değişimi ve iliş̧kili faktörler
}

\author{
Esra Pektaş ${ }^{1}$, Yasemin Çayır ${ }^{1}$, Zahide Koşan ${ }^{2}$ \\ ${ }^{1}$ Atatürk Üniversitesi Tıp Fakültesi Aile Hekimliği Ana Bilim Dalı, Erzurum, Türkiye \\ ${ }^{2}$ Atatürk Üniversitesi Tıp Fakültesi Halk Sağlı̆̆ı Ana Bilim Dalı, Erzurum, Türkiye
}

Weight change and associated factors in Atatürk University Faculty of Medicine employees

\section{ÖZET}

Giriș: Tüm dünyada olduğu gibi ülkemizde de fazla kilo ve obezite önemli bir halk sağlığı sorunudur. Türkiye'de erişkinlerin \%37'sinin fazla kilolu, \%32'sinin ise obez olduğu tahmin edilmektedir. Kilo değişimine etki eden birçok faktör olabilir. Bu çalışmada bir üniversite hastanesi çalışanlarının kohortunda kilo değişimine etki edebilecek faktörlerin incelenmesi amaçlanmıştır.

Yöntem: Çalışmamıza Nisan 2015-Ocak 2016 tarihleri arasında Atatürk Üniversitesi Tıp Fakültesi'nde çalışan 229 kişi katıldı. Katılımcıların sosyodemografik verileri, uyku ve yeme düzenleri ve fiziksel aktivite düzeyleri ile 6 ay boyunca üç defa $(0,3,6$. ay) 24 saatlik besin tüketimi bilgileri ve antropometrik ölçümleri alındı.

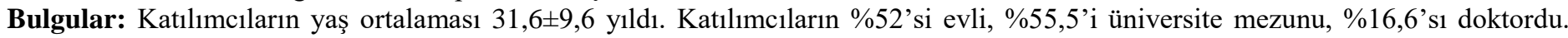
Başlangıçta çalışanların \%10,9'u obez, \%66'sı fazla kiloluydu. Altı aylık takip sonunda katılımcıların \%51,5'i aynı kiloda seyretti. Ortalama $0,2 \pm 2 \mathrm{~kg}$ alınd1, BMI $24,3 \mathrm{~kg} / \mathrm{m}^{2}$ 'den $24,5 \mathrm{~kg} / \mathrm{m}^{2}$ 'ye ve yağ oranı $\% 23,1$ 'den $\% 23,6$ 'ya çıktı. Kilo verenlerin günlük toplam alınan kalorinin ortalama \%15,3'ünü protein, \%41,3'ünü yă̆ ve \%43,5'ini karbonhidrattan aldığı görüldü. Kilo alanların ise üç besin öğesinden verenlere göre daha fazla tükettiği görüldü $(p<0,05)$. Düzenli spor yapanların ortalama $0,3 \mathrm{~kg}$ verdiği ve bel çevresinin ortalama 2,3 cm azaldığı görüldü. Başlangıçta normal kiloda olan bireylerin 6 aylık takip sonunda ortalama $0,4 \pm 1,8 \mathrm{~kg}$ alırken; obez olan bireylerin $0,2 \pm 1,8 \mathrm{~kg}$ verdiği görüldü $(\mathrm{p}=0,09)$. Altı aylık takiplerde kilo verenlerin alanlara göre ortalama uyku süresi daha fazlaydı (sirasiyla $8 \pm 1,9$ saat ve $7,2 \pm 1,9$ saat, $p<0,05$ ).

Sonuç: Çalışmamızda uyku süresi ve besin öğesi alımı ile kilo değişimi arasında ilişki olduğu saptandı. Bununla birlikte, cinsiyet, medeni durum, sigara içme durumu, yemek yeme düzeni, fiziksel aktivite durumu, spor yapma durumu, günlük kalori ihtiyacından fazla kalori alıp almama ile 6 aylık takiplerdeki kilo değişimi arasında ilişki olmadığı tespit edildi. Daha uzun süreli ve kilo alımına ve vermeye etki edebilecek başka faktörlerin de araştırıldığı çalışmalara ihtiyaç vardır.

Anahtar Kelimeler: obezite, beslenme, kilo değiş̧imi, üniversite çalışanı

\begin{abstract}
Introduction: Overweight and obesity is a major public health problem in Turkey like all over the world. It is estimated that 37\% of adults is overweight, and $32 \%$ of adults is obese in Turkey. There are many factors that affect weight change. We aimed to investigate the factors that can affect weight change in cohort of a university hospital employees.

Methods: 229 employees who work at Ataturk University Faculty of Medicine were enrolled to study between April-2015 and January2016. Subjects' socio-demographic data, sleep and eating patterns, and physical activity levels and 24-hour food consumption information and anthropometric measurements were taken three times $(0,3,6$ months) for 6 months.

Results: The mean age of participants was $31.6 \pm 9.6$ years. $52 \%$ of the participants were married, $55.5 \%$ were university graduates and $16.6 \%$ were doctors. $10.9 \%$ of participants were obese, $28.8 \%$ of them were overweight and $51.5 \%$ of participants remained in the same weight. The average $0.2 \pm 2 \mathrm{~kg}$ was gained, and BMI increased from $24.3 \mathrm{~kg} / \mathrm{m}^{2}$ to $24.5 \mathrm{~kg} / \mathrm{m}^{2}$ and total body fat percentage increased from $23.1 \%$ to $23.6 \%$. It was observed that $15.3 \%$ of consumed daily calories was protein, $41.3 \%$ was lipid and $43.5 \%$ was carbohydrates of individuals who lose weight. Participants who gained weight consumed more three food items more than participants who lost weight $(\mathrm{p}<0.05)$. It was observed that individuals who have regularly physical exercise lost weight a mean of $0.3 \mathrm{~kg}$, and waist circumference was reduced a mean of $2.3 \mathrm{~cm}$. At the end of the 6 month follow-up period, individuals with normal weight received an average of $0,4 \pm 1,8 \mathrm{~kg}$; while obese individuals lost $0.2 \pm 1.8 \mathrm{~kg}(\mathrm{p}=0,09)$. The average sleep duration was higher for those who lost weight on sixmonth follow-up than for the subjects who gained weight $(8 \pm 1.9$ hours and $7.2 \pm 1.9$ hours, respectively; $\mathrm{p}<0.05)$.

Conclusion: There was a relationship between sleep duration and nutrient intake with weight change in this study. However, there was no relationship between gender, marital status, smoking status, eating habit, physical activity status, sporting status, daily calorie intake, calorie intake, and weight change in 6 month follow-up. Further long-term trials should be based upon factors that may affect weight loss and weight gain.
\end{abstract}

Keywords: obesity, weight change, nutrition, university employees

Başvuru / Submission: Haziran / June 16, 2017

Kabul / Acceptance: Ağustos / Aug 01, 2017

Yazışma / Correspondence: Doç.Dr. Yasemin Çayır, Atatürk Üniversitesi Tıp Fakültesi Aile Hekimliği Ana Bilim Dalı, Erzurum, Türkiye

\begin{tabular}{|l|l|l|}
\hline E-MAIL & ORCID ID & DOI \\
\hline @ dryasemincayir@yahoo.com & iD orcid.org/0000-0001-9133-5460 & do 10.22391/920.321916 \\
\hline
\end{tabular}


Atıf / Cite: Pektas E, Cayir Y, Kosan Z. [Weight change and associated factors in Atatürk University Faculty of Medicine employees.] Fam Pract Palliat Care. 2017;2(2):1-4

\section{GİRIŞ}

Erişkinlerde en önemli sağlık problemlerinden birisi fazla kiloluluk ve obezitedir. Dünya Sağlık Örgütü verilerine göre Dünya nüfusunun $\% 35$ 'i fazla kilolu, $\% 11^{\prime} i$ ise obezdir. Türkiye'de ise erişkinlerin \%37'sinin fazla kilolu, \%32'sinin ise obez olduğu tahmin edilmektedir ${ }^{1}$. Gerek fazla kilolu olma ve gerekse obezite sağlıklı yaşamı ve yaşam süresini olumsuz etkiler. Her ikisi de kardiyovasküler sistem hastalıkları, hipertansiyon, insülin direnci ve ilişkili hastalıklar, tip 2 diyabet, safra taşları ve kolesistit, osteoartrit, çeşitli kanserler, solunum sistemi hastalıkları ve psikolojik sorunlarla yakından ilişkilidir. Normal kilolu erişkinlerin zaman içerisinde fazla kilolu olması, fazla kiloluların da obez olması sağlıkla ilgili riskleri artıracaktır ${ }^{2,3}$.

Aile hekimleri sağlık hizmetine ihtiyaç duyan herkese çok yönlü ve kapsamlı bakım vermek ve gerekli hallerde diğer sağlık personelini hizmet sunması için organize etmekten birinci derecede sorumlu hekimdir. Aile hekimliğinde tedavi edici sağlık hizmetlerindense koruyucu sağlık hizmetleri ön plandadır ${ }^{4,5}$. Bu bağlamda aile hekimleri bireylerin kilo almalarını engellemeyi ve kilo vermelerini kolaylaştırmayı sağlamalıdır. Zaman içerisinde erişkinlerin kilo almasına ya da vermesine etki edebilecek çok sayıda faktör mevcuttur ${ }^{6}$.

Ülkemizde y1llar içerisinde besin tüketim eğrilerinde değişimler olduğu gösterilmiştir. Taze sebze ve meyve ile hayvansal protein tüketiminin azaldığı ve şeker tüketiminin arttığı görülmüştür. Beslenme alışkanlıklarındaki değişiklikler, fizksel aktivite düzeyinin azalması, yaş ve cinsiyet zaman içerisinde kilo değişimine etki edebilecek faktörler arasında sayılabilir ${ }^{7}$. Erişkinlerde kilo almaya ya da vermeye etki eden faktörlerin tespit edilmesi aile hekimlerinin ve diğer klinisyenlerin takibini kolaylaştıracaktır. Bu çalışmada yaşam biçimleri ile rol model olması gereken bir grup olan sağlık çalışanlarının kohortunda kilo değişimine etki edebilecek faktörlerin incelenmesi amaçlanmıştır.

\section{YÖNTEM}

$\mathrm{Bu}$ çalışma prospektif kohort bir araştırma olarak planlandı. Çalışmamıza Atatürk Üniversitesi Tıp Fakültesi Klinik Araştırmalar Etik Kurulu'ndan gerekli izinler alındıktan sonra Nisan 2015-Ocak 2016 tarihleri arasında Atatürk Üniversitesi Tıp Fakültesi'nde çalışan ve çalışmaya katılmayı kabul eden 229 kişi alındı. On sekiz yaş altında olanlar, herhangi bir hastalık nedeniyle diyet tedavisi uygulananlar, herhangi bir hormon tedavisi alanlar, gebeler, morbid obezler çalışmaya dahil edilmedi.

Çalışmaya katılanlar 6 ay boyunca takip edildi. Standart bir form aracılığıyla katılımcıların yaş, cinsiyet, medeni durum, ailesel risk faktörleri (ailede obezite varlığı), eşlik eden hastalıklar, meslek, eğitim durumu, fiziksel aktivite düzeyi (hastaların beyanlarına göre sedanter, minimal aktif ve aktif), yeme düzeni, günlük ortalama uyku süresi ve kadınlarda doğum sayısı gibi özellikleri sorgulandı. Katılımcıların herhangi bir müdahale olmaksızın 6 ay boyunca üç defa $(0,3,6$. ay) 24 saatlik besin tüketimi bilgileri ve antropometrik ölçümleri alındı. Hastaların günlük kalori ihtiyacı ve günlük alınan makro ve mikro besinlerin tüketim analizi, yüzde değerleri lisanslı Türkçe versiyon Beslenme Bilgi Sistemi (Bebis $\left.{ }^{\circledR}\right)$ ile incelendi.

Hastaların Beden kitle indeksi, total vücut yağ oranı gibi ölçümler biyoelektrik impedans özellikli profesyonel tartı ile (Tanita $\left.{ }^{\circledR}\right)$ ve bel çevresi, kalça çevresi ölçümleri esnemeyen mezura ile yapıldı. Çalışmaya başlamadan önce Atatürk Üniversitesi Tıp Fakültesi Klinik Araştırmalar Etik Kurulu'ndan izin alındı. (B.30.2.ATA.0.01.00/79). Çalışmaya katılanlara çalışmanın amacı anlatılarak bilgilendirilmiş onam formu imzalatıldı.

\section{İstatistiksel Analiz}

Elde edilen veriler SPSS 20.0 for Windows (SPSS, Inc., Chicago, IL) programı ile analiz edildi. Kategorik verilerin karşılaştırılmasında ki-kare testi ve ortalamalar arasındaki farkın belirlenmesinde student-t testi uygulandı. Çalışmanın başlangıcında, 3. ayın ve 6 . ayın sonundaki ölçümlerin karşılaştırılmasında paired sample t-test kullanıldı. Numerik veriler arasındaki korelasyon ilişkisini incelemek için pearson korelasyon analizi yapıld1.

Anlamlılık düzeyi $\mathrm{p}<0,05$ kabul edildi.

\section{BULGULAR}

Katılımcıların yaş ortalaması $31,6 \pm 9,6$ yıldı. Katılımcıların \%52'si evli, \%55,5'i üniversite mezunu, \%16,6's1 doktordu (Tablo 1).

Çalışmanın başında katılımcıların \%10,9'u (n=25) obez, $\% 28,8$ 'i $(\mathrm{n}=66)$ fazla kiloluydu. Bekarlarda normal kilolu oranı $\% 68,2$ (n=73) iken; evlilerde \%41,2 $(n=49)$ idi $(p<0,05)$. Obezlerin oranı bekarlarda \%3,7 $(n=4)$ iken; bu oran evlilerde $\% 17,6(\mathrm{n}=21)$ idi $(\mathrm{p}<0,05)$.

Çalışmanın sonunda obezlerin oranı \%11,8 (n=27) iken; fazla kiloluların oranı aynı kalmıştı. Altı aylık takip sonunda katılımcıların \%51,5'i aynı kiloda ( \pm 100 gr) seyretti. Çalışma sonunda katılımcıların \%28,8'i (n=66) kilo aldı ve \%19,7'si $(\mathrm{n}=45)$ kilo verdi. Çalışma boyunca ortalama $0,2 \pm 2 \mathrm{~kg}$ alındı. Beden Kitle İndeksi (BKİ) 24,3 kg/m²' den $24,5 \mathrm{~kg} / \mathrm{m}^{2}$ 'ye ve total vücut yağ oranı \%23,1'den \%23,6'ya çıktı (Tablo 2).

Katılımcıların medeni durumuna göre 6 ayda kilo alıp almama durumu karşılaştırıldığında aralarında anlamlı fark olmadığı görüldü $(p>0,05)$. Evlilerin \%56,3'ü $(n=67)$ aynı kiloda kalırken; bekarların \%46,7'si (n=50) aynı kiloda kalmıştı.

Katılımcıların cinsiyete göre 6 ayda kilo alıp almama durumu karşılaştırıldığında kadın ve erkek arasında anlamlı fark yoktu $(\mathrm{p}>0,05)$. Erkeklerin \%46,6's1 ( $\mathrm{n}=55)$, kadınların ise \%53,4'ü $(n=63) 6$ aylık takip sonunda aynı kiloda kaldı. Kilo verenlerin günlük toplam alınan kalorinin ortalama $\% 15,3$ 'ünü protein, \%41,3'ünü yağ ve \%43,5'ini karbonhidrattan aldığı görüldü. Kilo alanların ise üç besin öğesinden de verenlere göre anlamlı düzeyde daha fazla tükettiği görüldü $(\mathrm{p}<0,05)$.

Hastalardan alınan 24 saatlik besin tüketim bilgileri analiz edildiğinde ve tüketilen besin öğelerinin günlük alınan kaloriyi karşılama yüzdeleri hesaplandığında, 6 aylık süreçte yă alımının azaldığı, karbonhidrat alımının arttığ görülmüştür. 
Tablo 1. Katılımcıların bazı özellikleri, $n(\%)$

\begin{tabular}{ll}
\hline Özellik & $\mathrm{n}(\%)$ \\
& \\
\hline Medeni durum & \\
Evli & $119(\% 52)$ \\
Bekar & $107(\% 46,7)$ \\
Boşanmış & $3(\% 1,3)$ \\
Cinsiyet & \\
Kadın & $107(\% 46,7)$ \\
Erkek & $122(\% 53,3)$ \\
Eğitim Durumu & \\
İlkokul mezunu & $6(2,6)$ \\
Ortaokul mezunu & $18(7,8)$ \\
Lise mezunu & $78(34,1)$ \\
Üniversite mezunu & $127(55,5)$ \\
Meslek & \\
Doktor & $38(\% 16,6)$ \\
Hemşire & $99(\% 43,2)$ \\
Personel & $48(\% 21)$ \\
Memur & $44(\% 19,2)$ \\
Sigara içme durumu & \\
Hiç içmeyenler & $111(\% 48,5)$ \\
Bırakanlar & $22(\% 9,6)$ \\
İçenler & $96(\% 41,9)$ \\
Ailede obezite varlığı & \\
Var & $166(\% 85,6)$ \\
Yok & $33(\% 14,4)$ \\
Yemek yeme düzeni & \\
Düzenli & $166(72,5)$ \\
Düzensiz & \\
Fiziksel aktivite durumu & \\
Sedanter & \\
Minimal aktif & \\
Aktif & \\
\hline
\end{tabular}

Düzenli spor yapanların ortalama $0,3 \mathrm{~kg}$ verdiği ve bel çevresinin ortalama $2,3 \mathrm{~cm}$ azaldığı görüldü. Başlangıçta normal kiloda olan bireylerin 6 aylık takip sonunda ortalama $0,4 \pm 1,8 \mathrm{~kg}$ alırken; obez olan bireylerin $0,2 \pm 1,8 \mathrm{~kg}$ verdiği görüldü $(p=0,09)$. Altı aylık takiplerde kilo verenlerin alanlara göre ortalama uyku süresi daha fazlaydı (sırasıyla $8 \pm 1,9$ saat ve 7,2 $\pm 1,9$ saat; $p<0,05)$.

Tablo 2. Antropometrik ölçümlerin başlangıç, 3.ay ve 6.ay ortalamaları, ortalama \pm standart sapma (ss)

\begin{tabular}{|c|c|c|c|c|}
\hline \multicolumn{3}{|c|}{ Başlangıç } & 3.ay & 6.ay \\
\hline \multirow{2}{*}{\multicolumn{2}{|c|}{$\begin{array}{l}\text { Vücut Ağırlığı } \\
(\mathbf{k g}) \\
\text { BKİ }\left(\mathbf{k g} / \mathbf{m}^{2}\right)\end{array}$}} & $68,4 \pm 14,7$ & $67,9 \pm 14,5$ & $68,7 \pm 14,7$ \\
\hline & & $24,3 \pm 4,4$ & $24,2 \pm 4,3$ & $24,5 \pm 4,3$ \\
\hline $\begin{array}{l}\text { Bel } \\
(\mathbf{c m})\end{array}$ & Çevresi & $83,4 \pm 13,4$ & $81,9 \pm 13$ & $82,1 \pm 13,1$ \\
\hline $\begin{array}{l}\text { Yă̆ } \\
(\%)\end{array}$ & Oranı & $23,1 \pm 8,7$ & $23,1 \pm 8,2$ & $23,6 \pm 8,3$ \\
\hline
\end{tabular}

\section{TARTIŞMA}

Bu çalışmada Atatürk Üniversitesi Tıp Fakültesi çalışanlarının 6 aylık takip sonunda kilo aldıkları ve bununla ilişkili olarak da BKİ ile toplam vücut yağ oranlarının artığı görüldü. Sağlıklı yaşam biçimi davranışlarının geliştirilmesinde ve devam ettirilmesinde sağlık çalışanlarına özellikle rol model olma ve sağlık eğitimi yönünden hizmet verme gibi önemli görevler düşmektedir. $\mathrm{Bu}$ nedenle öncelikle sağlık çalışanları kendi yaşam biçimlerini kontrol etmelidirler. Bu çalışmada sağlık çalışanlarının zaman içinde kilo aldıkları saptanmıştır. Bu durumun uzun dönem sonuçlarını görebilmek için daha uzun süreli takipler yapılan çalışmalara ihtiyaç vardır.

Obezite ve fazla kilonun etiyolojisi multifaktöriyeldir. Obezite ve fazla kiloluluk birçok kronik hastalıkla birlikte olabilmektedir. Özellikle obezite tek başına kronik hastalıklardan bağımsız olarak artmış mortalite nedenidir ${ }^{7}$. Obezitede temelde alınan ve harcanan enerji arasındaki dengenin değişmesi ile vücutta anormal derecede yağ birikimi olmaktadır. Ayrıca çevresel, biyokimyasal, genetik, sosyokültürel, psikolojik gibi pek çok faktör de obezite gelişimine katkıda bulunabilmektedir. İdeal kiloyu korumak yada ideal kiloya ulaşmak için sağlıklı beslenme ve düzenli egzersiz alışkanlığının kazanılmasına ihtiyaç duyulmaktadır. Çalışmalar özellikle normal kiloluların fazla kilolu sınıfa girmesi, fazla kilolu bireylerin de obezite sınıfina girmesinin engellenmesi gerektiğini vurgulamaktadır ${ }^{8-10}$. Nitekim çalışmamızda katılımcıların ancak yarısının 6 aylık süreçte kilolarını koruduğu saptanmıştır. Başlangıç ölçümlerine göre \%30'unun kilo aldığı ve buna bağlı olarak obezite sınıfına girenlerin oranının arttığı izlenmiştir. $\mathrm{Bu}$ durum bireylerin normal kilolarını korumalarının sağlanması için daha fazla önlem alınması gerektiğini göstermektedir.

Çalışmamızda bekarların daha fazla oranda normal kilolu olduğu, evlilerin ise daha yüksek oranda obez olduğu görüldü. Daha önce yapılan çalışmalarda da benzer şekilde evlilerde obezitenin daha yüksek olduğunu göstermiştir ${ }^{11}$. Bu durumu yaşla birlikte evli olanların oranının artmasına ve özellikle kadınlarda gebelik ve emzirme sürecinde kilo alımının artmasına bağlayabiliriz.

Çalışmamızda düzenli spor yapanların 6 aylık takibin sonunda kilo verdiği, spor yapmayanların ise kilo aldığı saptandı. Düzenli fiziksel aktivitenin fazla kilo ve obezitenin kardiyak ve metabolik etkilerini azalttığı ve kilo vermeyi kolaylaştırdığ 1 bilinmektedir. Özellikle fazla kilolu ve obez bireylerde 6 ay içerisinde \%5-10’luk kilo kaybının sağlanması durumunda obeziteyle ilişkili tüm metabolik komplikasyonların gerilediği bilinmektedir ${ }^{1,7}$.

Kadınlarda fazla kiloluluk ve obeziteyi etkileyen faktörler arasında doğum sayısı da bulunmaktadır. Doğum sayısı arttıkça BKI'nin, bel çevresinin, bel/kalça oranının arttığı ve vücut yağ dağılımının değiştiği belirtilmiştir ${ }^{1}$. Bizim çalışmamızda da kadınlarda doğum sayısı arttıkça BKİ, bel çevresi ve yağ oranının arttığ 1 izlenmiştir.

Diyet ve kontrol grubunun karşılaştırıldığı ve 14 hafta takip edildiği bir çalışmada, kontrol grubunun 14 haftada kilo ve yağ oranının azalmasına rağmen bel çevresinin arttığı görülmüştür 12. Bacon ve ark. yaptıkları bir çalışmada diyet yapmayan 
kadınlarda 3.ayda vücut ağırlıklarının arttığını, 6.ayda azaldığını ve sonuçta 6 aylık süreçte BKİnin aynı kaldığını göstermişleridir 13. Bizim çalıșmamızda ise katılımcıların 3.ayda vücut ağırlığı, bel çevresi ve bel/kalça oranının düştüğü, fakat 6.ayda BKİ ve vücut ağırlığı artarken; bel çevresi ve bel/kalça oranı azalmış olarak bulundu. Bu durumu çalışmanın başlangıcında katılımcıların beslenme ve fiziksel aktivite düzeyinin sorgulanmasının kişilerde farkındalık yaratarak kısa vadede kilo vermesine neden olmasına bağlayabiliriz. Kişide oluşturulan fiziksel aktivite düzeyi üzerindeki farkındalık kişilerin kilosunun artmasına rağmen bel çevresinin ve bel/kalça oranının azalmasını açıklayabilir. Ayrıca kilo değişiminde mevsimsel değişikliklerin de etkisi olduğu bilinmektedir. $\mathrm{Bu}$ yüzden çalışmanın ilk üç ayının yaz mevsiminde olması da kişilerin ilk üç ayda kilo vermesini ve son üç ayda kilo almasını açıklayabilir. Yapılan çalışmalarda yıl boyunca izlenen kişilerde kilo ve BKİ'nin yaz aylarında azaldığı ve sonbahar aylarında arttığı görülmüştür ${ }^{14}$. Bu durum da çalışmamızın bulgularını etkilemiştir.

Bu çalışmada 6 aylık takipler sonunda kilo veren kişilerin daha çok uyuduğu tespit edildi. Uyku süresi arttıkça vücut ağırlığının azaldığ1 görüldü. Uyku süresi ile kilo arasındaki ilişsinin incelendiği çalışmalarda çelişkili sonuçlar rapor edilmiştir. Her ne kadar bir çok çalışma sağlıklı kilonun korunması için optimum uyku süresi verse de bazı çalışmalarda artan kilo ile azalmış uyku süresi arasında $U$ şekilli ilişki olduğu bulunmuştur. İspanya'da yapılan bir çalışmada 7 saat uyku süresi ile 6 veya daha az saat uyku süresi olanlar karşılaştırıldığında; 6 ya da daha az saatlik uyku süresi olanlarda obezite oranının \%39 daha fazla olduğu bulunmuştur 15-17. Özellikle, Hart ve arkadaşlarının geç ergenlik ve erken yetişkinlik döneminde yaptığı çalışmada yüksek BKİ ile çok kısa uyku süresi (gecede 6 saatten az) veya çok uzun uyku süresi (gecede 9 saatten fazla) arasında U !<şeklinde ilişki olduğu rapor edilmiştir ${ }^{18}$. Yapılan çalışmalarda bel çevresi ile uyku süresi arasında negatif korelasyon bildirilmiştir. Bizim çalışmamızda da buna paralel sonuçlar görülmüştür.

Orta düzeyde karbonhidrat, yüksek düzeyde protein ve düşük düzeyde yağ ile beslenenlerin daha çok kilo verdiğine dair çalışmalar mevcuttur 19. Çalışmamızda ise takiplerde kilo verenlerin $\% 15,3$ oranında protein, $\% 41,3$ oranında yağ ve \%43,5 oranında karbonhidrat alımı olduğu görüldü. Yüksek proteinle, düşük yağla beslenenlerin ve orta karbonhidratla beslenenlerin daha çok kilo aldığı tespit edildi. Kişilerin kilo alıp vermesini etkileyen pek çok faktör vardır, ayrıca çalışmamızda elde edilen veriler kişilerin beyanlarına dayalıdır. $\mathrm{Bu}$ nedenle bu sonucu pekiştirecek başka çalışmalara ihtiyaç vardir.

Çalışmamızın kısıtlılıkları arasında beslenme ile kilo arasındaki ilişkinin daha ayrıntılı incelenebilmesi açısından bireye özel beslenme analizinin daha ayrıntılı olarak yapılamaması sayılabilir. Öte yandan çalışmanın prospektif bir çalışma olması üstünlük olarak değerlendirilebilir.

\section{SONUÇ}

Sonuç olarak bu çalışmada, uyku süresi ve besin öğesi alımı ile kilo değişimi arasında ilişki olduğu saptandı. Bununla birlikte, cinsiyet, medeni durum, sigara içme durumu, yemek yeme düzeni, fiziksel aktivite durumu, spor yapma durumu, günlük kalori ihtiyacından fazla kalori alıp almama ile 6 aylık takiplerdeki kilo değişimi arasında ilişki olmadığı tespit edildi.

Aile hekimleri bireylerin kilo takibinde belli aralıklarla antropometrik ölçümler kullanarak, 24 saatlik besin tüketimi yöntemi hatırlama veya kayıt tutma tekniği kullanarak temel besin öğelerinden hangi düzeyde aldığını tespit edebilirler. Ayrıca, bireylerin kilo takibini yaparken çalışmamızda tespit edilen kilo alımına ve vermeye etki edebilecek faktörler açısından bireyleri yakından takip edebilirler.

\section{Çıkar çatışması: Yoktur.}

Finansal destek: Yoktur.

\section{KAYNAKLAR}

1. Obezite tanı ve tedavi kılavuzu, Türkiye Endokrinoloji ve Metabolizma Derneği, Miki Matbaacılık San. ve Tic. Ltd. Şti. 2014, Ankara.

2. Cayir Y, Aslan SM, Akturk Z. The effect of pedometer use on physical activity and body weight in obese women. Eur J Sport Sci 2014;28:1-6.

3. Cayir Y, Isik M, Akturk Z. Recommendations For The Management of Obesity Medicine Science International Medical Journal 2014;3(2):1332-9.

4. Kara İH, Günvar T, Sunay D, et al. Aile Hekimliği Uygulama Eğitimi: Nerede, Ne Kadar, Nasıl ve Ne Zaman? Konuralp Tip Dergisi 2016:8(1);65-71.

5. Aile Hekimliği Avrupa Tanımı. WONCA Avrupa 2005 Basımı Türkçe Çevirisi. Türkiye Aile Hekimleri Uzmanlık Derneği Yayınları-4, Nisan 2011.

6. Birinci Basamak Hekimler İçin Obezite ile Mücadele El Kitabı. Anıl Matbaacılık Ltd. Şti. Sağlık Bakanlığı Yayın No : 904. Ankara, 2013.

7. Türkiye Beslenme ve Sağlık Araștırması (TBSA) 2010. http://www.sagem.gov.tr/TBSA_Beslenme_Yayini.pdf. Erişim Tarihi: 20.07.2017.

8. Cayir, Y, Akturk, Z. Clinical Effectiveness of Group-Based Education with Individual Counseling in Obese Women. Acta Medica Mediterranea. 2014:30(4):903-6.

9. Prince SA, Reed JL, McFetridge C, et al. Correlates of sedentary behaviour in adults: a systematic review. Obes Rev 2017; doi: 10.1111/obr.12529.

10. Abdelaal M, le Roux CW, Docherty NG. Morbidity and mortality associated with obesity. Ann Transl Med 2017;5(7):161.

11. Aasheim ET, Aylwin SJ, Radhakrishnan ST, et al. Assessment of obesity beyond body mass index to determine benefit of treatment. Clin Obes 2011;1(2-3):77-84.

12. Maskarinec G, Takata Y, Pagano I, et al. Trends and Dietary Determinants of Overweight and Obesity in A Multiethnic Population. Obesity 2006;14:717-26.

13. Kerksick CM, Wismann-Bunn J, Fogt D, et al. Changes in weight loss, body composition and cardiovascular disease risk after altering macronutrient distributions during a regular exercise program in obese women. Nutr J 2010; 9:59.

14. Bacon L, Keim NL, Van Loan MD, et al. Evaluating a 'non-diet' wellness intervention for improvement of metabolic fitness, psychological wellbeing and eating and activity behaviors. International Journal of Obesity 2002;26,854-65.

15. Ma Y, Olendzki BC, Li W, et al. Seasonal variation in food intake, physical activity, and body weight in a predominantly overweight population. Eur J Clin Nutr 2006;60(4):519-28.

16. Patel SR, Hu FB. Short sleep duration and weight gain: a systematic review. Obesity (Silver Spring) 2008;16(3): 643-53.

17. Kalak N, Marka S, Beck J, et al. Association between subjective actual sleep duration, subjective sleep need, age, body mass index, and gender in a large sample of young adults. Neuropsychiatr Dis Treat 2015;11:10713.

18. Knutson KL, Cauter EV. Associations between sleep loss and increased risk of obesity and diabetes. Ann.N.Y.Acad.Sci 2008;1129:287-304.

19. Hart CN, LaRose JG, Fava JL, et al. The Association between Time in Bed and Obesity Risk in Young Adults. Behav Sleep Med 2013;11(5):10

20. Sacks FM, Bray GA, Carey VJ, et al. Comparison of Weight-Loss Diets with Different Compositions of Fat, Protein, and Carbohydrates. N Engl J Med 2009;26;360(9):859-73. 